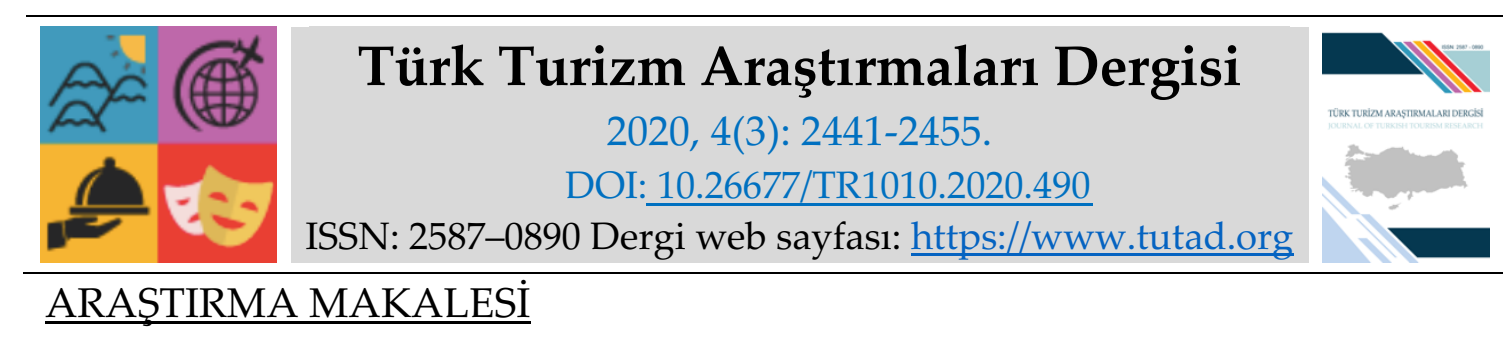

\title{
Hizmet Ortamı, Müşteri Memnuniyeti ve Tekrar Ziyaret Etme Niyeti İlişkisi: Resort Otellerde Bir Araştırma
}

Doç. Dr. Savaş ARTUĞER, Muğla Sıtkı Koçman Üniversitesi, Turizm Fakültesi, Muğla, e-posta: artugersavas@yahoo.com ORCID: https://orcid.org/0000-0003-1272-2361

Öğr. Gör. Songül KILINÇ ŞAHİN, Muğla Sıtkı Koçman Üniversitesi, Ula Ali Koçman Meslek, Muğla, e-posta: songulkilinc@mu.edu.tr

ORCID: https://orcid.org/0000-0002-3510-9220

Öz

$\mathrm{Bu}$ araştırmanın amacl; hizmet ortamı, müşteri memnuniyeti ve tekrar ziyaret etme niyeti arasındaki ilişkileri ortaya çıkarmaktır. Araştırmanın evreni, Muğla ilinin Marmaris ilçesinde faaliyet gösteren beş yıldızlı resort otellerde, 1 Temmuz-30 Ağustos 2019 tarihleri arasında konaklayan yabancı turistlerden oluşmaktadır. Araştırmada 310 yabancı turistten veri toplanmıştır. Elde edilen verilerin analizinde aritmetik ortalama, standart sapma, doğrulayıcı faktör analizi, güvenirlik analizlerinden faydalanılmıştır. Bununla birlikte değişkenler arasındaki ilişki, Yapısal Eşitlik Modelleme (YEM) Tekniği kullanılarak analiz edilmiştir. Araştırmadan elde edilen sonuçlara göre, otellerdeki hizmet ortamı unsurlarından çevre koşulları, düzen ve dekorun müşteri memnuniyetini etkilemediği, işaret ve sembollerin ise müşteri memnuniyetini etkilediği ortaya çıkmıştır. Araştırmada ayrıca, müşteri memnuniyetinin müşterilerin tekrar ziyaret etme niyetleri üzerinde etkili olduğu sonucuna ulaşılmıştır.

Anahtar Kelimeler: Hizmet Ortamı, Müşteri Memnuniyeti, Tekrar Ziyaret Etme Niyeti, Resort Oteller, Marmaris.

Makale Gönderme Tarihi: 20.02.2020

Makale Kabul Tarihi: 01.07.2020

\section{Önerilen Atıf:}

Artuğer, S. ve Kılınç Şahin, S. (2020). Hizmet Ortamı, Müşteri Memnuniyeti ve Tekrar Ziyaret Etme Niyeti İlişkisi: Resort Otellerde Bir Araştırma, Türk Turizm Araştırmaları Dergisi, 4(3): 24412455.

(c) 2020 Türk Turizm Araştırmaları Dergisi. 


\title{
Journal of Turkish Tourism Research 2020, 4(3): 2441-2455. \\ DOI: $10.26677 /$ TR1010.2020.490
}

ISSN: 2587-0890 Journal Homepage: https://www.tutad.org

\section{RESEARCH PAPER}

\section{Relationship Between Servicescape, Customer Satisfaction and Revisit Intention: A Research at Resort Hotels}

Associate Prof. Dr. Savaş ARTUĞER, Muğla Sıtkı Koçman University, Faculty of Tourism, Muğla, e-mail: artugersavas@yahoo.com

ORCID: https://orcid.org/0000-0003-1272-2361

Lecturer Songül KILINÇ ŞAHİN, Muğla Sıtkı Koçman University, Ula Ali Koçman Vocational High School, Muğla, e-mail: songulkilinc@mu.edu.tr

ORCID: https://orcid.org/0000-0002-3510-9220

\begin{abstract}
The aim of this research, to reveal the relationship between servicescape, customer satisfaction and revisit intention. The research population consists of foreign tourists staying in five-star resort hotels in the Marmaris district of Muğla between July 1-August 30, 2019. In the study, data were collected from 310 foreign tourists. Mean, standard deviation, confirmatory factor analysis and reliability analysis were used in the analysis of the data obtained. However, the relationship between variables was analyzed by using the Structural Equation Modeling Technique (SEM). According to the results obtained from the research, it has been revealed that ambient conditions, layout and decor do not affect customer satisfaction, while signs and symbols affect customer satisfaction. The research also concludes that customer satisfaction has an impact on customers' revisit intentions.
\end{abstract}

Keywords: Servicescape, Customer Satisfaction, Revisit Intention, Resort Hotels, Marmaris.

Received: 20.02 .2020

Accepted: 01.07.2020

\section{Suggested Citation:}

Artuğer, S. and Kılınç Şahin, S. (2020). Relationship Between Servicescape, Customer Satisfaction and Revisit Intention: A Research at Resort Hotels, Journal of Turkish Tourism Research, 4(3): 2441-2455.

(C) 2020 Türk Turizm Araştırmaları Dergisi. 


\section{Gíriş}

Ağırlama odaklı firmalarda, özellikle otel endüstrisinde, müşterilere iyi bir deneyim sunmak temel bir unsur haline gelmiştir (Ariffin vd., 2013:128). Günümüzde birçok müşteri bir oteli, sadece uyumak için bir yer olarak görmemektedir. Otel müşterileri unutulmaz deneyimler yaşayabilmek için, kendilerine sürprizler yapan ve zevk alabilecekleri özel şeyler sunan işletmeler aramaktadırlar. Otel işletmeleri müşterilerin beklediği ilgi ve konforu sunarken, unutulmaz bir deneyim için, ek dokunuşlar yapmalıdırlar. Bu noktada hizmet ortamı unsurları, müşterilerin hem unutulmaz deneyimler yaşamasına hem de memnuniyetlerine önemli katkılar sağlayacaktır (Lockwood ve Pyun, 2020:41). Bununla birlikte hizmet ortamı unsurları, soyut özelliklere sahip hizmetlerin kalitesine dair müşterilere önemli ipuçları sağlar. Ayrıca hizmet ortamı, müşterilerin hizmet personeli ile herhangi bir etkileşime girmeden önce, bir hizmet işletmesine ilişkin ilk izlenimlerin oluşmasına yardımcı olur (Lin, 2009:23).

Müşteri memnuniyeti, bir tüketicinin satın almış olduğu ürün ve hizmetler hakkında, satış sonrası değerlendirme yapması olarak tanımlanmaktadır (Lin ve Wang, 2006:273). Müşteri memnuniyeti, müşterilerin ihtiyaçlarını ve isteklerini karşılamada bir işletmenin başarısı için hayati öneme sahiptir (Han vd., 2011:620). Bununla birlikte müşteri memnuniyeti, tüm pazarlama faaliyetlerinin en önemli sonuçlarından birisidir (Han ve Back, 2007:10). Otel işletmelerinde odaların kalitesi, personelin performansı, hizmetlerin çeşitliliği, güvenlik, odaların büyüklüğü ve konforu, banyoların temiz olması, yiyecek içecek kalitesi gibi birçok unsur müşteri memnuniyetini etkilemektedir (Gu ve Ryan, 2008:338-339). Tüm bu unsurlar müşteri memnuniyetini etkilemekle birlikte, günümüzdeki tüketicilerin beklentileri dikkate alındığında sadece bu unsurlarla müşteri memnuniyetini sağlamak yetersiz kalabilmektedir. Bu nedenle hizmet ortamı unsurları, otel işletmelerinde müşteri memnuniyetinin sağlanmasında önemli bir rol oynayabilir. Yapılan bazı çalışmalar bunu desteklemektedir (Adzoyi ve Klutse, 2015; Ali ve Amin, 2014; Lap-Kwong, 2017). Ayrıca memnun olan müşterilerin işletmeyi tekrar ziyaret etme niyetleri de artmaktadır (Han ve Back, 2007:10).

Yukarıda belirtilen bilgiler ışı̆̆ında bu araştırmanın amacı; hizmet ortamı, müşteri memnuniyeti ve tekrar ziyaret etme niyeti arasındaki ilişkileri ortaya çıarmaktır. Bu amaç doğrultusunda Muğla ilinin Marmaris ilçesinde faaliyet gösteren beş yıldızlı resort otellerde bir araştırma yapılmıştır. Yapılan çalışmadan elde edilen sonuçlarla otel işletme yöneticilerine, müşteri memnuniyetinin sağlanmasında hangi hizmet ortamı unsurlarının etkili olduğunun ve müşteri memnuniyeti-tekrar ziyaret etme niyeti arasındaki ilişkinin açıklanması hedeflenmiştir. $\mathrm{Bu}$ ilişkilerin ortaya konulmasıyla otel işletmelerinin pazarlama stratejilerine ve planlamalarına katkı yapılması ve böylece işletmelere rekabet avantajı sağlanması, araştırmanın önemini ortaya koymaktadır.

\section{LITERATÜR TARAMASI}

\section{Hizmet Ortamı}

Hizmet ortamı kavramı literatürde farklı yazarlar tarafından farklı şekilde kavramsallaştırılmıştır. Bitner (1992) tarafından kullanılan hizmet ortamı (servicescape) kavramını; Baker (1987) "Fiziksel Çevre", Arnould vd., (1996) "Ekonomik Çevre", Turley ve Milliman (2000) "Pazarlama Çevresi", Mahrabian ve Rusell (1974) ile Weinrach (2000) "Çevresel Psikoloji", Mathwich, Malhotra ve Rigdon (2001) "Etkileşimli Alan", Roy ve Tai (2003) "Mağaza Çevresi", Weinrach (2000) "Psikolojik Çevre", Cronin (2003) "Hizmet Çevresi" olarak kavramsallaştırmıştır (Harris ve Ezeh, 2008:391; Juhari vd., 2012:620). 
Hizmet ortamı; hizmetlerin sunulduğu, bir hizmet işletmesinin fiziksel ortamı veya çevresi olarak tanımlanmaktadır (Bitner, 1992:65). Kaminakis vd., (2019:71) hizmet ortamını, konaklama, yeme ve içme gibi önemli konaklama faaliyetlerinin gerçekleştiği yapay ortamlar olarak tanımlamıştır. Bitner'e göre (1992) hizmet ortamı, doğal ortamlardan ziyade, yapay ortamlar olarak kabul edilir. Hizmet ortamı özellikle oteller, restoranlar, temalı parklar, bankalar ve hastaneler gibi hizmet işletmelerinde, tüketici davranışlarını etkileyebilir ve özgül bir işletme imajı yaratabilir (Lee vd., 2019:400).

Yazarlar tarafından farklı şekilde kavramsallaştırılan hizmet ortamı, farklı yazarlar tarafından farklı şekilde boyutlandırılmıştır. Bitner (1992:60) hizmet ortamını üç boyut olarak belirlemiştir. Bu boyutlar; çevresel koşullar, mekansal düzen ve işlevsellik, işaretler, semboller ve sanat eserleridir. Çevresel koşullar; iklimlendirme, koku, gürültü, renk, müzik ve aydınlatma gibi unsurlardan oluşmaktadır (Bitner, 1992:65) Çevresel koşullar tüketicilerin fiziksel ve fizyolojik durumlarını etkiler. Örneğin sıcaklık, aydınlatma, renk veya koku duygusal reaksiyonlar ortaya çıkarır (Lee vd., 2019:400). Mekansal düzen ve işlevsellik; makinelerin, ekipmanların, mobilyaların ve diğer fiziksel nesnelerin düzenlenme biçimlerini, bu nesnelerin büyüklüğünü ve şeklini ve bunlar arasındaki uyumu ifade eder (Lam vd., 2011:560). İşaretler, semboller ve sanat eserleri; fiziksel ortamın mimari tasarımı, iç tasarımı, dekoru, malzeme kalitesi, tabela vb. unsurları içerir (Ellen ve Zhang, 2014:89). Bir yapının dış ve iç kısmında gösterilen işaretler, semboller ve sanat eserleri, açık iletişimcilere örnektir. İşletmenin adı, yönlendirici levhalar ve davranış kurallarını anlatan uyarıcılar bunlara örnek verilebilir (Kim ve Moon, 2009:145). Wakefield ve Blodgett (1999) mekansal düzen-işlevsellik ve estetik olarak iki boyuta ayırmıştır. Lucas (2003), çevresel koşullar, oturma konforu, iç dekor, temizlik ve düzen olmak üzere beş boyut şeklinde belirlemiştir. Ryu ve Jang (2008) ise, tesis estetiği, aydınlatma, çevresel koşullar, düzen ve yemek ekipmanları olmak üzere beş olarak belirlemiştir (Lockwood ve Pyun, 2020). Turley ve Milliman (2000) ise bu unsurları beş gruba ayırmıştır. Bu unsurlar; dış değişkenler, genel iç değişkenler, düzen değişkenleri, satın alma değişkenleri ve insan değişkenleridir.

\section{Hizmet Ortamının Müşteri Memnuniyeti Üzerine Etkisi}

Turizm işletmelerinde hizmet ortamının müşteri memnuniyeti üzerindeki etkisini araştıran çalışmalar incelendiğinde çalışmaların genellikle oteller (Adzoyi ve Klutse, 2015; Ali ve Amin 2014; Lap-Kwong, 2017; Lin, 2009; Mohd Wahid vd., 2012) ve restoranlar (Fidan ve Artuğer, 2018; Han ve Ryu, 2009; Heung ve Gu, 2012; Ryu, 2010) üzerinde yapıldığı görülmektedir.

Adyozi ve Klutse (2015), Ganadaki 1-3 yıldızlı otellerde yaptıkları araştırmada, otellerdeki hizmet ortamının müşteri memnuniyeti üzerinde etkili olduğu sonucuna ulaşmışlardır. Araştırmada sonucunda, araç-gereç, koku ve aydınlatmanın müşteri memnuniyeti üzerinde daha fazla etkili olduğu ortaya çıkmıştır. Ali ve Amin (2014) Çin'in Nanjing, Hangzhou ve Shanghai eyaletlerindeki resort otellerde bir araştırma yapmışlardır. Yazarlar, fiziksel varlıkların müşteri memnuniyeti üzerinde etkili olduğu sonucuna ulaşmışlardır. Lap-Kwong, (2017) otel restoranında yaptığı araştırmada, temizlik unsurunun müşteri memnuniyetini etkileyen en önemli faktör olduğunu ortaya çıkarmıştır. Lin (2009), otel barlarında kullanılan müzik ve renklerin müşteri memnuniyetini etkilediği sonucuna ulaşmıştır. Mohd Wahid vd., (2012) Malyezya'nın Perak bölgesinde faaliyet gösteren otellerde yaptığı bir araştırmada, fiziksel çevrenin boyutlarından olan içsel unsurların (ses, koku, sıcaklık, aydınlatma vb.) müşteri memnuniyetini etkilediğini belirlemişlerdir. Bununla birlikte yazarlar, dişsal unsurların (binanın yüksekliği, rengi, tesisteki otopark olanakları, peyzaj düzenlemesi vb.) müşteri memnuniyeti üzerinde etkili olmadığı sonucuna ulaşmışlardır. 
Fidan ve Artuğer (2018) İstanbul'un Bahçelievler ve Bakırköy ilçelerinde faaliyet gösteren birinci sınıf restoranlarda yaptıkları bir araştırmada, restoranlardaki atmosferik unsurların müşteri memnuniyeti üzerinde etkili olduğunu ortaya çıkmışlardır. Araştırmada, restoran estetiği, aydınlatma, masa düzeni ve hizmet personelinin müşterilerin memnuniyeti üzerinde etkisi olduğu, restoran ambiyansının ve oturma düzeninin ise etkili olmadığı sonucuna ulaşılmıştır. Han ve Ryu (2009) restoranlardaki dekor ve sanat eserlerinin müşteri memnuniyeti üzerinde pozitif bir etkisinin olduğunu ortaya çıkarmışlardır. Heung ve $\mathrm{Gu}$ (2012) Hong Kong'daki lüks restoranlarda yaptığı bir araştırmada, restoranlardaki oturma düzeni, çalışanlar, ambiyans, tesis estetiği ve pencerelerin görüntüsü gibi atmosferik unsurların müşteri memnuniyeti üzerinde etkili olduğunu belirlemişlerdir. Ryu (2010) lüks restoranlarda yaptığ1 araştırmada, tesis estetiği, aydınlatma, ambiyans, oturma düzeni ve hizmet personelinin müşteri memnuniyeti üzerinde etkili olduğunu ortaya çıkarmıştır. Tüm bu ampirik bilgilere dayanarak aşağıdaki hipotezler geliştirilmiştir:

H1: Çevre koşulları müşteri memnuniyeti üzerinde etkilidir.

H2: Düzen unsuru müşteri memnuniyeti üzerinde etkilidir.

H3: Dekor unsuru müşteri memnuniyeti üzerinde etkilidir.

H4: İşaretler ve semboller müşteri memnuniyeti üzerinde etkilidir.

\section{Müşteri Memnuniyetinin Tekrar Ziyaret Etme Niyeti Üzerine Etkisi}

İlgili literatür incelendiğinde, turizm işletmelerinde müşteri memnuniyetinin tekrar ziyaret etme niyeti üzerindeki etkisini ortaya çıkaran çalışmaların olduğu görülmektedir (Ali ve Amin, 2014; Ali ve Omar, 2014; Jani ve Han, 2014; Mannan vd., 2019; Marinkovic vd., 2014; Raza vd., 2012)

Ali ve Amin (2014) Çin'in Nanjing, Hangzhou ve Shanghai eyaletlerindeki resort otellerde yaptıkları bir araştırmada müşteri memnuniyetinin tekrar ziyaret etme niyeti üzerinde etkili olduğunu belirlemişlerdir. Benzer şekilde, Ali ve Omar (2014) Malyezya'nın Langkawi bölgesinde faaliyet gösteren resort otellerde yaptıkları araştırmada, müşteri memnuniyetinin müşterilerin tekrar ziyaret etme niyetleri üzerinde etkili olduğunu ortaya çıkarmışlardır. Jani ve Han (2014) Güney Kore'de dört ve beş yıldızlı otellerde yaptıkları bir araştırmada, müşteri memnuniyetinin tekrar ziyaret etme niyeti üzerinde etkili olduğunu ortaya çıkarmışlardır. Raza vd. (2012) lüks otellerde, hizmet kalitesi, algılanan değer, müşteri memnuniyeti ve tekrar ziyaret arasındaki ilişkileri incelemişlerdir. Araştırma sonucunda, müşteri memnuniyetinin müşterilerin tekrar ziyaret etme niyetleri üzerinde etkili olduğu sonucuna ulaşılmıştır. Manan vd. (2019) restoranlarda yaptıkları araştırmada, müşteri memnuniyetinin tekrar ziyaret etme niyeti üzerinde etkili olduğunu belirlemişlerdir. Marinkovic vd., (2014) Sırbistan'da restoran işletmelerinde yaptıkları araştırmada, müşteri memnuniyetinin tekrar ziyaret etme niyeti üzerinde etkili olduğunu belirlemişlerdir. Bu bilgiler ışığında aşağıdaki hipotez geliştirilmiştir:

H5: Müşteri memnuniyetinin tekrar ziyaret etme niyeti üzerinde anlamlı bir etkisi vardır.

Literatürden faydalanılarak belirlenen hipotezler çerçevesinde oluşturulan araştırma modeli Şekil 1'de yer almaktadır. Şekil 1'de de görüldüğü gibi otel hizmet ortamı, müşteri memnuniyeti ve tekrar ziyaret etme niyeti arasındaki ilişkiler araştırılmaktadır. 


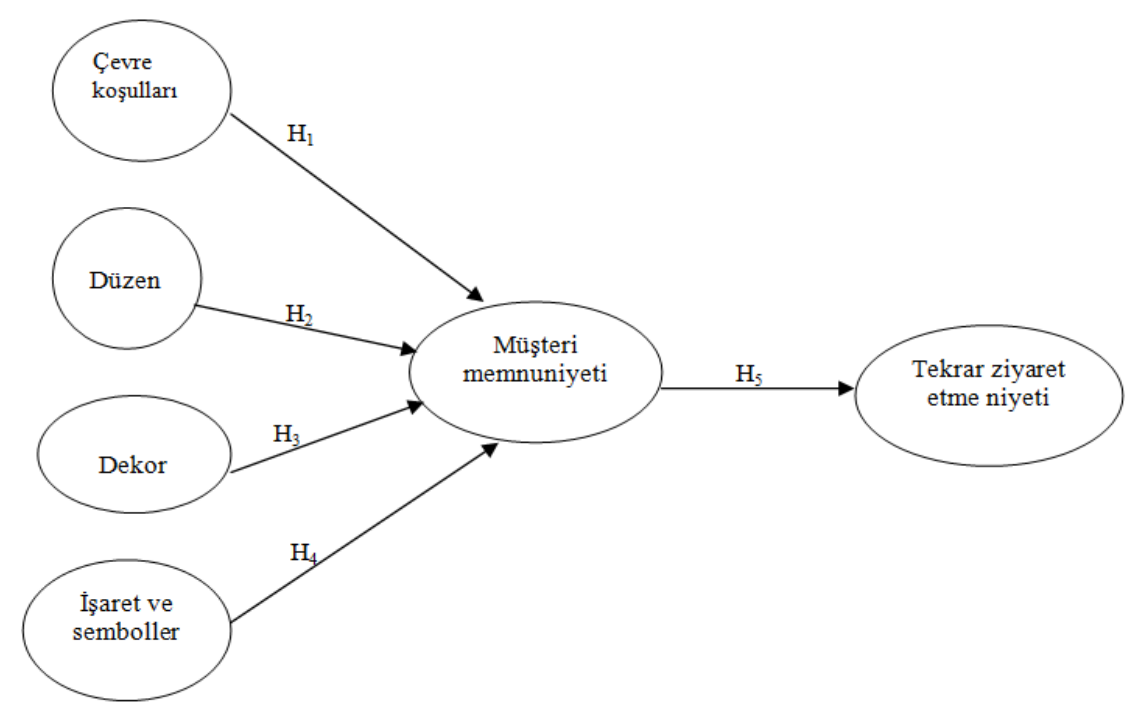

Şekil 1: Araştırmanın Modeli

\section{YÖNTEM}

\section{Veri Toplama Yöntemi}

$\mathrm{Bu}$ araştırmada veri toplama aracı olarak anket tekniği kullanılmıştır. Hazırlanan anket üç bölümden oluşmaktadır. Birinci bölümde katılımcıların demografik özelliklerine (cinsiyet, yaş, eğitim, milliyet) yer verilmiştir. İkinci bölümde ise 13 madde ve dört temel boyuttan oluşan (çevre koşulları, düzen, dekor, işaret ve semboller) otel hizmet ortamını ölçen ölçek yer almaktadır. Üçüncü bölümde ise, müşteri memnuniyeti ve tekrar ziyaret etme niyeti üç'er ifade ile ölçülmüştür.

Otel hizmet ortamını ölçen ifadeler, Dedeoğlu vd., (2015) tarafından yapılan çalışmadan alınarak hazırlanmıştır. Müşteri memnuniyetine ilişkin sorular Back ve Parks (2003), tekrar ziyaret etme niyetine ilişkin sorular ise Durna vd., (2015) tarafından yapılan çalışmalardan alınmıştır. Katılımcıların her üç ölçekte yer alan her bir ifadeye ait katılım düzeyleri "Hiç Katılmıyorum=1", "Az Katılıyorum=2", "Orta Düzeyde Katılıyorum=3", "Çok Katılıyorum=4" ve "Tamamen Katılıyorum=5" şeklinde 5'li Likert ölçeği doğrultusunda derecelendirilmiştir. Uygulanan anketler İngilizce dilinde hazırlanmıştır.

\section{Evren ve Örneklem}

Hizmet ortamı, müşteri memnuniyeti ve tekrar ziyaret etme niyeti arasındaki ilişkileri ortaya çıarmayı amaçlayan bu araştırmanın evreni, Muğla ilinin Marmaris ilçesinde faaliyet gösteren beş yıldızlı resort otellerde, 1 Temmuz-30 Ağustos 2019 tarihleri arasında konaklayan yabancı turistlerden oluşmaktadır. İlgili tarihlerde Muğla İl Kültür ve Turizm Müdürlügüu internet sayfasından Marmaris'te 17 adet beş yıldızlı otel olduğu belirlenmiştir. Öncelikle bu 17 otel ile görüşmeler yapılmıştır. Bu otellerden sekiz tanesi anket yaptırmayı kabul etmemiştir. Dolayısıyla anket çalışması diğer dokuz otel ile gerçekleştirilmiştir. Anket yapılan oteller her şey dahil sistemi uygulayan resort otellerdir. 
$\mathrm{Bu}$ araştırmada evrenin listesinin belirlenmesi mümkün olmadığından, olasılıklı olmayan örnekleme yöntemlerinden kolayda örnekleme yöntemi kullanılmıştır. Yapısal eşitlik modellemesi kullanılması durumunda örneklem sayısının kaç olması gerektiği konusunda farklı görüşler bulunmaktadır. Hair vd. (2014:573), yapısal eşitlik modellemesi kullanılması durumunda 200 kişinin örneklem hacmi için yeterli olacağını vurgulamaktadır. Schumacker ve Lomax (2010: 42)'a göre ise bu sayı, 250-500 arasında olabilir. Bu araştırmada 300 kişiye ulaşılması hedeflenmiştir. Araştırma sonunda 310 anket toplanmıştır. Anketler yapılırken her otelden eşit sayıda anket toplanmasına dikkat edilmiştir. Anketler, araştırmayı yürüten kişiler tarafından, otel yönetiminin otel içerisinde izin verdiği alanlarda ankete katılmayı kabul eden turistler ile yüz yüze görüşülerek yapılmıştır.

\section{Verilerin Analizi}

Araştırmada öncelikle katılımcıların demografik özelliklerine (cinsiyet, yaş, eğitim, milliyet) ilişkin frekans ve yüzde dağılımları verilmiştir. Yabancı turistlerin otel hizmet ortamı, müşteri memnuniyeti ve tekrar ziyaret etme niyetlerine ilişkin görüşlerini betimlemek amacıyla, aritmetik ortalama ve standart sapma değerleri hesaplanmıştır.

Araştırmada yer alan değişkenler arasındaki ilişkiler Yapısal Eşitlik Modelleme Tekniği (YEM) kullanılarak analiz edilmiştir. Yapısal eşitlik modellemesi Maksimum Olabilirlik Tahmini (Maksimum Likelihood Estimation) yöntemi kullanılarak yapılmıştır. Bu araştırmada, yapısal eşitlik modellemesi için Anderson ve Gerbing'in (1988) önerdiği iki aşamalı yaklaşım uygulanmıştır. Bu nedenle öncelikle ölçüm modelinin geçerliğini ve güvenirliğini test etmek amacıyla doğrulayıcı faktör analizi (DFA) uygulanmıştır. Daha sonra çalışmada önerilen modeli test etmek amaciyla YEM yapılmıştır.

YEM uygulanmadan önce kayıp verilerin olup olmadığına, aykırı(uç) değerlere ve verilerin normal dağılım (çok değişkenli normallik) gösterip göstermediğine bakılmıştır (Woo vd., 2015). Verilerde kayıp veriye rastlanmamıştır. Uç değerler için Amos programında, Mahalanobis Distance değerleri kontrol edilmiş ve bazı uç değerlerin olduğu tespit edilmiştir. Uç değerlere sahip olan anketler (altı adet) veri setinden çıarıldığı için 304 anket ile analizler yapılmıştır. Verilerin normal dağılıma uyup uymadığı, çarpıklık ve basıklık değerleri incelenerek belirlenmiştir. Shiel ve Cartwright'a (2015:28) göre verilerin normal dağılımı için çarpıklık ve basılık değerlerinin -1 ve +1 arasında değer alması gerekmektedir. Yapılan analiz sonucunda, her bir ifadeye ait çarpıklık ve basıklık değerlerinin -1 ve +1 arasında olduğu belirlenmiştir.

\section{BULGULAR}

Tablo 1'de ankete katılan otel müşterilerinin demografik özeliklerine ait frekans ve yüzde dağılımları yer almaktadır. Tablo 1'de yer alan bulgulara göre katılımcıların \%54,3'ü erkek, $\% 43,8$ 'i kadındır. Katılımcıların yarısından fazlası (\%57,9) 41-61 yaş aralı̆̆ındadır. Katılımcıların çoğunluğu $(\% 89,2)$, lise, ön lisans ve lisans düzeyinde eğitime sahip kişilerden oluşmaktadır. Katılımcılar ağırlıklı olarak Rus, Hollandalı ve İngiliz turistlerden oluşmaktadır. 
Tablo 1. Katılımcıların Demografik Özelliklerine Göre Dağılımı

\begin{tabular}{|c|c|c|c|}
\hline Değişken & Grup & (f) & $(\%)$ \\
\hline \multirow{4}{*}{ Cinsiyet } & Erkek & 165 & 54,3 \\
\hline & Kadın & 133 & 43,8 \\
\hline & Kayıp veri & 6 & 1,9 \\
\hline & Toplam & 304 & 100 \\
\hline \multirow[t]{8}{*}{ Yaş } & 20 ve alt 1 & 33 & 10,9 \\
\hline & $21-30$ & 60 & 19,7 \\
\hline & $31-40$ & 32 & 10,5 \\
\hline & $41-50$ & 55 & 18,1 \\
\hline & $51-60$ & 78 & 25,7 \\
\hline & 61 ve üzeri & 43 & 14,1 \\
\hline & Kayıp veri & 3 & 1 \\
\hline & Toplam & 304 & 100 \\
\hline \multirow[t]{7}{*}{ Eğitim } & İlköğretim & 11 & 3,6 \\
\hline & Lise & 154 & 50,7 \\
\hline & Önlisans & 65 & 21,4 \\
\hline & Lisans & 52 & 17,1 \\
\hline & Lisansüstü & 16 & 5,3 \\
\hline & Kayıp veri & 6 & 1,9 \\
\hline & Toplam & 304 & 100 \\
\hline \multirow[t]{7}{*}{ Milliyet } & İngiliz & 59 & 19,4 \\
\hline & Alman & 50 & 16,4 \\
\hline & Rus & 105 & 34,5 \\
\hline & Hollandalı & 62 & 20,4 \\
\hline & $\begin{array}{l}\text { Diğer (Ukraynalı, Sırp, Lübnanlı., } \\
\text { İskandinav) }\end{array}$ & 24 & 7,9 \\
\hline & Kayıp veri & 4 & 1,4 \\
\hline & Toplam & 304 & 100 \\
\hline
\end{tabular}

Tablo 2. Otellerdeki Hizmet Ortamı Unsurlara İlişkin Aritmetik Ortalama ve Standart Sapma Değerleri

\begin{tabular}{|l|c|c|}
\hline \multicolumn{1}{|c|}{ Boyutlar ve İfadeler } & $\begin{array}{c}\text { Aritmetik } \\
\text { Ort. }\end{array}$ & $\begin{array}{c}\text { Std. } \\
\text { Sapma }\end{array}$ \\
\hline Çevre Koşulları & $\mathbf{3 , 2 8}$ & $\mathbf{1 , 0 9}$ \\
\hline Otelde, ortak kullanım alanlarındaki ısıtma/soğutma sistemleri yeterlidir. & 3,13 & 1,21 \\
\hline Otelde çalan fon müziği keyiflidir. & 3,24 & 1,20 \\
\hline Otelde hoş bir koku vardır. & 3,30 & 1,18 \\
\hline Otelin ortak kullanım alanlarındaki aydınlatmalar yeterlidir. & 3,43 & 1,14 \\
\hline Düzen & $\mathbf{3 , 5 7}$ & $\mathbf{1 , 0 8}$ \\
\hline Oteldeki asansörlere erişim kolaydır. & 3,50 & 1,19 \\
\hline Otelin düzeni havuz alanlarına erişim için uygundur. & 3,57 & 1,19 \\
\hline Otelin düzeni ortak kullanım alanlarına erişim için uygundur. & 3,62 & 1,10 \\
\hline Dekor & $\mathbf{3 , 5 2}$ & $\mathbf{0 , 9 1}$ \\
\hline Otelin zemin ve duvar renkleri hoştur. & 3,49 & 1,07 \\
\hline Odalardaki mobilyaların kalitesi yüksektir. & 3,49 & 1,02 \\
\hline Ortak alanlarda kullanılan mobilyaların kalitesi yüksektir. & 3,57 & 1,01 \\
\hline İşaretler ve Semboller & $\mathbf{3 , 6 3}$ & $\mathbf{0 , 8 3}$ \\
\hline Oteldeki tabelalar yeterince büyüktür. & 3,63 & 0,90 \\
\hline Oteldeki tabelalar kolaylıkla anlaşılabilmektedir. & 3,63 & 0,90 \\
\hline
\end{tabular}


Tablo 2'de yer alan otellerdeki hizmet ortamı unsurlara ilişkin aritmetik ortalamalar incelendiğinde, tüm boyutlara ait ortalamaların ölçek orta puanı olan 3'ün biraz üzerinde olduğu görülmektedir. Hizmet ortamına ilişkin nispeten en yüksek ortalamanın işaretler ve semboller boyutuna ait $\left({ }^{x}=3,63\right)$ olduğu görülmektedir. Tablo $2^{\prime}$ deki veriler dikkate alındığında, katılımcıların konakladıkları oteller ile ilgili hizmet ortamı unsurlarına ilişkin algılamalarının orta düzeyde olduğu söylenebilir.

Tablo 3. Müşteri Memnuniyeti ve Tekrar Ziyaret Etme Niyetine İlişkin Aritmetik Ortalama ve Standart Sapma Değerleri

\begin{tabular}{|l|c|c|}
\hline \multicolumn{1}{|c|}{ Boyutlar ve İfadeler } & $\begin{array}{c}\text { Aritemtik } \\
\text { ort. }\end{array}$ & Std. sapma \\
\hline Müşteri Memnuniyeti & $\mathbf{3 , 8 1}$ & $\mathbf{0 , 9 3}$ \\
\hline Genel olarak, bu otelde kalmaya karar verdiğim için mutluyum. & 3,76 & 1,02 \\
\hline Bu otelde kalmakla doğru bir şey yaptı̆̆ımı düşünüyorum. & 3,77 & 1,06 \\
\hline Genel olarak, bu otelde kalmaya karar verdiğim için memnunum. & 3,88 & 1,01 \\
\hline Tekrar Ziyaret Etme Niyeti & $\mathbf{3 , 5 7}$ & $\mathbf{0 , 9 8}$ \\
\hline Gelecekte bu otelde tekrar kalmak isterim. & 3,57 & 1,06 \\
\hline Bu otele daha sık gelmek isterim. & 3,65 & 1,04 \\
\hline Gelecekte bu otelde konaklama ihtimalim var. & 3,50 & 1,20 \\
\hline
\end{tabular}

Tablo 3'te katılımcıların konakladıkları otellerdeki memnuniyet düzeyleri ve tekrar ziyaret etme niyetlerine ilişkin aritmetik ortalama ve standart sapma değerleri yer almaktadır. Tablo 3'teki veriler incelendiğinde katılımcıların memnuniyet düzeylerinin ölçek orta puanı olan 3 'ün üzerinde olduğu görülmektedir. Bununla birlikte, katılımcıların konakladıkları oteli tekrar ziyaret etme niyetlerinin memnuniyetlerine göre daha düşük olduğu görülmektedir.

Tablo 4'teki modele ait uyum iyiliği değerleri incelendiğinde; $\chi^{2}=347,392, \mathrm{df}=117, \chi^{2} / \mathrm{df}=2,96$, $\mathrm{p}<0,001, \mathrm{RMSA}=0,07, \mathrm{AGFI}=0,85, \mathrm{GFI}=0,90, \mathrm{CFI}=0,95, \mathrm{NFI}=0,92$ olduğu görülmektedir. $\mathrm{Bu}$ değerlere göre ölçüm modelindeki uyum değerleri kabul edilebilir düzeydedir (Hoe, 2008; Engel vd., 2003).

Ölçekteki yapı geçerliğini (construct validity) belirlemek için yakınsak/uyuşum (convergent validity) ve ayırt edici (discriminant validitiy) geçerliğine bakılmıştır. Yakınsak geçerliği değerlendirmede üç yöntem kullanılmıştır: Faktör yükleri, CR (bileşik güvenirlik) ve AVE (açılanan ortalama varyans) değerleridir (Hair vd., 2014: 618-619).

Hair vd.'ne göre (2014: 618) doğrulayıcı faktör analizinde faktör yükleri 0,70 ve üzeri olmalıdır, ancak 0,50 ve üzerinde kabul edilebilir bir değerdir. Yapılan faktör analizi sonucunda, otel hizmet atmosferini ölçen ölçekte yer alan; işaretler ve semboller boyutundan bir ifadenin faktör yükü 0,50 ' den düşük olduğu için faktör analizinden çıkarılmıştır. Tablo $4^{\prime}$ teki diğer ifadelere ait faktör yüklerine bakıldığında 0,70 'in üzerinde olduğu görülmektedir. Literatürde, AVE değerinin 0,50 ve üzerinde, $C R$ değerinin ise 0,70 ve üzerinde olması gerektiği vurgulanmaktadır (Hair vd., 2014: 619). Tablo 4'teki veriler incelendiğinde tüm boyutlara ait AVE değerlerinin 0,60, CR değerlerinin ise 0,70'in üzerinde olduğunu görülmektedir.

Ayırt edici geçerlilikte ise, AVE değerlerinin karekökleri ile yapılar arasındaki korelasyon katsayıları karşılaştırılır. Yapılar arasındaki korelasyon değerlerinin AVE değerlerinin kareköklerinden düşük olması gerekir (Fornell ve Larcker, 1981). Tablo 5'teki veriler incelendiğinde yapılar arasındaki korelasyon katsayılarının AVE karekök değerlerinden düşük olduğu görülmektedir. Tüm bulgular birlikte değerlendirildiğinde, ölçeğin yapı geçerliğinin sağlandığı söylenebilir. 
Tablo 4. Doğrulayıcı Faktör Analizi Sonuçları

\begin{tabular}{|c|c|c|c|c|}
\hline Faktörler ve İfadeler & $\begin{array}{l}\text { Faktör } \\
\text { Yükleri }\end{array}$ & $\begin{array}{l}\text { Cronbach's } \\
\text { Alpha }\end{array}$ & CR & AVE \\
\hline Çevre Koşulları & & 0,93 & 0,93 & 0,76 \\
\hline $\begin{array}{l}\text { Otelde, ortak kullanım alanlarındaki } \\
\text { 1sitma/soğutma sistemleri yeterlidir. }\end{array}$ & 0,82 & & & \\
\hline Otelde çalan fon müziği keyiflidir. & 0,86 & & & \\
\hline Otelde hoş bir koku vardır. & 0,91 & & & \\
\hline $\begin{array}{l}\text { Otelin ortak kullanım alanlarındaki aydınlatmalar } \\
\text { yeterlidir. }\end{array}$ & 0,89 & & & \\
\hline Düzen & & 0,92 & 0,92 & 0,79 \\
\hline Oteldeki asansörlere erişim kolaydır. & 0,88 & & & \\
\hline $\begin{array}{l}\text { Otelin düzeni havuz alanlarına erişim için } \\
\text { uygundur. }\end{array}$ & 0,91 & & & \\
\hline $\begin{array}{l}\text { Otelin düzeni ortak kullanım alanlarına erişim için } \\
\text { uygundur. }\end{array}$ & 0,88 & & & \\
\hline Dekor & & 0,85 & 0,87 & 0,69 \\
\hline Otelin zemin ve duvar renkleri hoştur. & 0,83 & & & \\
\hline Odalardaki mobilyaların kalitesi yüksektir. & 0,82 & & & \\
\hline $\begin{array}{l}\text { Ortak alanlarda kullanılan mobilyaların kalitesi } \\
\text { yüksektir. }\end{array}$ & 0,84 & & & \\
\hline İşaretler ve Semboller & & 0,83 & 0,83 & 0,71 \\
\hline Oteldeki tabelalar yeterince büyüktür. & 0,89 & & & \\
\hline Oteldeki tabelalar kolaylıkla anlaşılabilmektedir. & 0,79 & & & \\
\hline Müşteri Memnuniyeti & & 0,88 & 0,89 & 0,73 \\
\hline $\begin{array}{l}\text { Genel olarak, bu otelde kalmaya karar verdiğim } \\
\text { için mutluyum. }\end{array}$ & 0,81 & & & \\
\hline $\begin{array}{l}\text { Bu otelde kalmakla doğru bir şey yaptığımı } \\
\text { düşünüyorum. }\end{array}$ & 0,91 & & & \\
\hline $\begin{array}{l}\text { Genel olarak, bu otelde kalmaya karar verdiğim } \\
\text { için memnunum. }\end{array}$ & 0,83 & & & \\
\hline Tekrar Ziyaret Etme Niyeti & & 0,86 & 0,88 & 0,71 \\
\hline Gelecekte bu otelde tekrar kalmak isterim. & 0,82 & & & \\
\hline Bu otele daha sık gelmek isterim. & 0,88 & & & \\
\hline Gelecekte bu otelde konaklama ihtimalim var. & 0,83 & & & \\
\hline
\end{tabular}

NOT: CR: bileşik güvenirlik, AVE: Açıklanan ortalama varyans

Tablo 5. Korelasyon Katsayıları ve AVE Karekök Değerleri

\begin{tabular}{|l|l|l|l|l|l|l|}
\hline & $\begin{array}{l}\text { Çevre } \\
\text { Koşulları }\end{array}$ & Düzen & Dekor & $\begin{array}{l}\text { İşaretler ve } \\
\text { Semboller }\end{array}$ & $\begin{array}{l}\text { Müşteri } \\
\text { Memnuniyeti }\end{array}$ & $\begin{array}{l}\text { Tekrar } \\
\text { Ziyaret Etme } \\
\text { Niyeti }\end{array}$ \\
\hline Çevre Koşulları & $\mathbf{0 , 8 7 1}$ & & & & & \\
\hline Düzen & 0,745 & $\mathbf{0 , 8 8 8}$ & & & & \\
\hline Dekor & 0,540 & 0,739 & $\mathbf{0 , 8 3 0}$ & & & \\
\hline $\begin{array}{l}\text { İşaretler ve } \\
\text { Semboller }\end{array}$ & 0,355 & 0,540 & 0,633 & $\mathbf{0 , 8 4 2}$ & & \\
\hline $\begin{array}{l}\text { Müşteri } \\
\text { Memnuniyeti }\end{array}$ & 0,270 & 0,375 & 0,389 & 0,434 & $\mathbf{0 , 8 5 4}$ & \\
\hline $\begin{array}{l}\text { Tekrar Ziyaret } \\
\text { Etme Niyeti }\end{array}$ & 0,212 & 0,386 & 0,442 & 0,509 & 0,729 & $\mathbf{0 , 8 4 2}$ \\
\hline
\end{tabular}

Not: AVE karekökleri köşegen (diagonal) ve koyu olarak verilmiştir 
Tablo 6. Yapısal Eşitlik Modeli ve Hipotezlere İlişkin Bulgular

\begin{tabular}{|c|c|c|c|c|c|}
\hline Hipotezler & $\begin{array}{l}\text { Standardize } \\
\text { edilmiş } \\
\text { regresyon } \\
\text { katsayıları } \\
(\beta)\end{array}$ & $\begin{array}{l}\text { Standart } \\
\text { hata }\end{array}$ & t değerleri & p değeri & $\begin{array}{l}\text { Hipotez } \\
\text { sonuçları }\end{array}$ \\
\hline H1: Çevre Koşulları $\longrightarrow$ Memnuniyet & $-0,06$ & 0,08 & $-0,59$ & 0,54 & Ret \\
\hline $\mathrm{H}_{2}:$ Düzen $\longrightarrow$ Memnuniyet & $-0,20$ & 0,13 & 1,18 & 0,23 & Ret \\
\hline $\mathrm{H}_{3}:$ Dekor $\longrightarrow$ Memnuniyet & 0,04 & 0,12 & 0,34 & 0,73 & Ret \\
\hline $\mathrm{H}_{4}:$ İşaret ve Sembol $\longrightarrow$ Memnuniyet & 0,40 & 0,11 & 3,86 & 0,00 & Kabul \\
\hline $\mathrm{H}_{5}:$ Memnuniyet $\longrightarrow$ Tekrar ziyaret & 0,86 & 0,09 & 11,94 & 0,00 & Kabul \\
\hline \multicolumn{6}{|c|}{$\begin{array}{l}\text { Uyum indeksleri: p:0,000 } \chi^{2}: 360,421, \mathrm{df}: 121, \chi^{2} / \mathrm{df}=2,97, \text { CFI:0,95, GFI: 0,90, NFI:0,92, RMSEA:0,07, AGFI:0,85 } \boldsymbol{R}^{2}: 0,31 \\
\text { (memnuniyet) } \\
\boldsymbol{R}^{2}: 0,74 \text { (tekrar ziyaret) }\end{array}$} \\
\hline
\end{tabular}

Tablo 6'da yapısal eşitlik modeline ilişkin uyum değerleri ve hipotez testi sonuçları yer almaktadır. Tablo 6'daki modele ait uyum iyiliği değerlerine bakıldığında $\chi^{2}=360,421, \mathrm{df}=121$, $\chi^{2} / \mathrm{df}=2,97 \quad \mathrm{p}<0.000, \quad \mathrm{RMSEA}=0.07, \quad$ AGFI $=0.85, \quad \mathrm{GFI}=0.90, \quad \mathrm{CFI}=0.96, \quad \mathrm{NFI}=0.92$ olduğu görülmektedir. Bu değerler ölçüm modelinin uyum değerlerinin kabul edilebilir düzeyde olduğunu göstermektedir (Hoe, 2008; Engel vd., 2003).

Tablo 6'daki veriler incelendiğinde, otellerdeki çevre koşullarının $(\beta=-0.06, p>0.05)$, düzenin $(\beta=-$ $0.02, p>0.05)$ ve dekorun $(\beta=0.04, p>0.05)$ müşteri memnuniyeti üzerinde anlamlı bir etkisinin olmadığı görülmektedir. Bu nedenle, H1, H2 ve H3 hipotezleri ret edilmiştir. Bununla birlikte, otellerdeki işaret ve sembollerin müşteri memnuniyeti üzerinde anlamlı bir etkisinin olduğu görülmektedir. Dolayısıyla, H4 hipotezi kabul edilmiştir. Hesaplanan $\mathrm{R}^{2}=0,31$ değeri, modelin hizmet atmosferi unsurları (çevre koşulları, düzen, dekor, işaretler ve semboller) tarafından açıklama oranının \%31 olduğunu göstermektedir. Ayrıca müşteri memnuniyetinin tekrar ziyaret etme niyeti üzerinde anlamlı bir etkisinin olduğu belirlenmiş̧tir. Bu nedenle, $\mathbf{H 5}$ hipotezi de kabul edilmiştir. Hesaplanan $\mathrm{R}^{2}=0,74$ değeri, modelin memnuniyet tarafından açılama oranının \%74 olduğunu göstermektedir.

\section{SONUÇ ve ÖNERILER}

Hizmet ortamı, müşteri memnuniyeti ve tekrar ziyaret etme niyeti arasındaki ilişkileri ortaya çıkarmayı amaçlayan bu araştırmada, örneklem grubunda yer alan otel müşterilerinin konakladıkları otel ile ilgili hizmet ortamı algılamaları ve tekrar ziyaret etme niyetlerinin ölçekte orta değer olan 3 puanın biraz üzerinde olduğu belirlenmiştir. Bununla birlikte katılımcıların konakladıkları otel ile ilgili memnuniyet düzeylerinin hizmet ortamı algılamaları ve tekrar ziyaret etme niyetlerine göre daha yüksek olduğu ortaya çıkmıştır.

$\mathrm{Bu}$ araştırmada, otellerdeki hizmet ortamı unsurlarından çevre koşulları, düzen ve dekorun müşteri memnuniyetini etkilemediği, işaret ve sembollerin ise müşteri memnuniyetini etkilediği ortaya çıkmıştır. Araştırma kapsamında incelenen oteller her şey dahil sisteminde çalışan resort otellerdir. Dolaysıyla bu oteller, geniş bir alana yayılan otellerdir. Bu nedenle müşteriler bu otellerde, otel içinde gitmek istedikleri yeri kolay bulmak isteyebilirler. Bu noktada otellerdeki işaret ve yönlendirici levhaların önemi daha çok artmaktadır. Yee-Man Siu vd.'ne (2012) göre işaretler ve semboller, bir işletmede müşteri davranışlarını yönlendirmede ve hatta işletmelerin kültürel değerlerini müşterilere iletmede önemli araçlardır. Bu unsurlar, 
müşterilerin bir işletmedeki hizmet ortamı unsurlarına ilişkin ilk izlenimlerinin oluşmasında önemli bir rol oynar.

Araştırmada ayrıca, müşteri memnuniyetinin müşterilerin tekrar ziyaret etme niyetleri üzerinde etkili olduğu ortaya çıkmıştır. Literatürde de hem resort hem de dört ve beş yıldızlı oteller üzerine yapılan çalışmalarda, müşteri memnuniyetinin müşterilerin tekrar ziyaret etme niyetlerini etkilediği sonucu ortaya çıkmıştır (Ali ve Amin, 2014; Ali ve Omar, 2014; Jani ve Han, 2014).

Sonuç olarak hem bu araştırmadan elde edilen sonuçlar hem de literatürde konu ile ilgili yapılmış diğer çalışmalar dikkate alındığında, otellerdeki hizmet ortamı unsurlarının müşterilerin memnuniyetleri üzerinde önemli bir etkisinin olduğu anlaşılmaktadır. Bununla birlikte bu ve diğer yapılan çalışmalardan elde edilen sonuçlarda, bazı hizmet ortamı unsurlarının müşterilerin memnuniyetleri üzerinde etkili olmadığı da görülmektedir. $\mathrm{Bu}$ durum, müşteri profili, beklentileri ve/veya işletmenin türüne göre farklılık gösteriyor olabilir. İyi kurulmuş ve dizayn edilmiş hizmet ortamı unsurları müşteri memnuniyetini olumlu yönde etkilemekte, bunun soncunda da müşterilerin işletmeyi tekrar ziyaret etme niyetleri artmaktadır.

Otel işletmelerinde müşteri memnuniyetini etkileyen birçok farklı unsur (odaların kalitesi, personelin performansı, hizmet kalitesi, güvenlik gibi) bulunmaktadır (Choi ve Chu, 2001; Sunny-Hu vd., 2009). Tüm bu unsurlara ek olarak, hizmet ortamı unsurlarının da otel yöneticileri tarafından dikkatle incelenmesi gerekmektedir. Özellikle bu araştırma sonuçlarından yola çıkarak, otel yöneticilerinin daha fazla önem vermesi gereken nokta; müşterileri otel içerisinde doğru yönlendirecek işaret ve levhalar olduğu söylenebilir. Bu noktada işaret ve yönlendirici levhaların yeterli sayıda, yeterince büyük ve okunabilir olması ve kolaylıkla anlaşılabilir olması büyük önem arz etmektedir. Böylece müşteriler, büyük alana yayılmış bu otellerde gitmek istedikleri yerleri daha rahat ve kolay bulabileceklerdir. Bu sayede hem müşteri memnuniyeti sağlamada avantaj elde edilebilecek, hem de müşteri memnuniyeti yoluyla müşterilerin oteli tekrar ziyaret etme niyetleri arttırılmış olacaktır.

$\mathrm{Bu}$ araştırma, sahil kesiminde faaliyet gösteren her şey dahil sistemi uygulayan resort otellerinde yapılmıştır. Gelecekte yapılacak çalışmalar şehir otellerinde yapılabilir. Böylelikle aradaki farklılıklar ve/veya benzerlikler karşılaştırılabilinir.

\section{KAYNAKÇA}

Adzoyi, N. P. and Klutse, M. C. (2015). Servicescape, Customer Satisfaction and Loyalty in Ghanaian Hotels. Journal of Tourism, Hospitality and Sports, 10: 30-36.

Ali, F. and Amin, M. (2014). The Influence of Physical Environment on Emotions, Customer Satisfaction and Behavioural Intentions in Chinese Resort Hotel Industry, J. Global Business Advancement, 7(3): 249-266.

Ali. F. and Omar, R. (2014). Determinants of Customer Experience and Resulting Satisfaction and Revisit Intentions: PLS-SEM Approach towards Malaysian Resort Hotels, Asia-Pacific. Journal of Innovation in Hospitality and Tourism, 3(2): 175-193.

Anderson, J. C. and Gerbing, D. W. (1988). Structural Equation Modeling in Practice: A Review and Recommend Two-Step Approach, Psychological Bulletin, 103(3): 411-423. 
Ariffin, M. A. A., Nameghi, N. E. and Zakaria, I. N. (2013). The Effect of Hospitableness and Servicescape on Guest Satisfaction in the Hotel Industry, Canadian Journal of Administrative Sciences, 30: 127-137.

Back, K. and Parks, S. C. (2003). A Brand Loyalty Model Involving Cognitive, Affective, and Conative Brand Loyalty and Customer Satisfaction, Journal of Hospitality $\mathcal{E}$ Tourism Research, 27(4): 419-435.

Bitner, M. (1992). Servicescapes: The Impact of Physical Surroundings on Customers and Employees, Journal of Marketing, 56(2): 57-71.

Choi, T. Y. and Chu, R. (2001). Determinants of Hotel Guests' Satisfaction and Repeat Patronage in the Hong Kong Hotel Industry, Hospitality Management, 20: 277-297.

Dedeoğlu, B. B., Küçükergin, G. K. and Balıkçıŏlu, S. (2015). Understanding the Relationships of Servicescape, Value, Image, Pleasure, and Behavioral Intentions Among Hotel Customers, Journal of Travel \& Tourism Marketing, 32(1): 42-61.

Durna, U., Dedeoğlu, B. B. and Balıkçığlu, S. (2015). The Role of Servicescape and Image Perceptions of Customers on Behavioral Intentions in The Hotel Industry. International Journal of Contemporary Hospitality Management, 27(7): 1728-1748.

Ellen, T. and Zhang, R. (2014). Measuring the Effect of Company Restaurant Servicescape on Patrons' Emotional States and Behavioral Intentions, Journal of Foodservice Business Research, 17(2): 85-102.

Engel, K. S., Moosbrugger, H. and Müler, H. (2003). Evaluating the Fit of Structural Equation Models: Tests of Significance and Descriptive Goodness-of-Fit Measures. Methods of Psychological Research Online, 8(2): 23-74.

Fidan, D. ve Artuğer, S. (2018). Restoranlardaki Atmosferik Unsurların Müşteri Memnuniyeti Üzerine Etkisi, Journal of Tourism and Gastronomy Studies, 6(4): 267-284.

Fornell, C. and Larcker, D. F. (1981). Evaluating Structural Equation Models with Unobservable Variables and Measurement Error, Journal of Marketing Research, 18(1): 39-50.

Gu, H. and Ryan, C. (2008). Chinese Clientele at Chinese Hotels: Preferences and Satisfactions, International Journal of Hospitality Management, 27: 337-345.

Hair, J. F., Black, C. W., Babin, J. B. and Anderson, R. E. (2014). Multivariate Data Analysis (7th ed.). Upper Saddle River, NJ: Prentice Hall.

Han, H. and Back, J. K. (2007). Investigating the Effects of Consumption Emotions on Customer Satisfaction and Repeat Visit Intentions in the Lodging Industry, Journal of Hospitality \& Leisure Marketing, 15(3): 5-30.

Han, H. and Ryu, K. (2009). The Roles of The Physical Environment, Price Perception, and Customer Satisfaction in Determining Customer Loyalty in The Restaurant Industry, Journal of Hospitality \& Tourism Research, 33(4): 487-510.

Han, H., Kim, W. and Hyun, S. S. (2011). Switching Intention Model Development: Role of Service Performances, Customer Satisfaction, and Switching Barriers in The Hotel Industry, International Journal of Hospitality Management, 30: 619-629.

Harris, C. L. and Ezeh, C. (2008). Servicescape and Loyalty Intentions: An Empirical Investigation, European Journal of Marketing, 42(3/4): 390-422. 
Heung, V. C. and Gu, T. (2012). Influence of Restaurant Atmospherics on Patron Satisfaction and Behavioral Intentions, International Journal of Hospitality Management, 31(4): 1167-1177.

Hoe, L. S. (2008). Issues and Procedures in Adopting Structural Equation Modeling Technique, Journal of Applied Quantitative Methods, 3(1): 76-83.

Jani, D. and Han, H. (2014). Testing the Moderation Effect of Hotel Ambience on the Relationships Among Social Comparison, Affect, Satisfaction, and Behavioral Intentions, Journal of Travel \& Tourism Marketing, 31(6): 731-746.

Juhari, H. N., Ali. M. H. and Khair, N. (2012). The Shopping Mall Servicescape Affects Customer Satisfaction. 3rd international conference on business and economic research (3rd Icber 2012) Bandung, Indonesia.

Kaminakis, K., Karantinou, K., Koritos, C. and Gounaris, S. (2019). Hospitality Servicescape Effects on Customer-Employee İnteractions: A Multilevel Study, Tourism Management, 72: 130144.

Kim, G. W. and Moon, J. Y. (2009). Customers' Cognitive, Emotional, and Actionable Response to the Servicescape: A Test of The Moderating Effect of the Restaurant Type, International Journal of Hospitality Management, 28(1): 144-156.

Lam, W. L, Chan, K. W., Fong, D. and Lo, F. (2011). Does the Look Matter? The Impact of Casino Servicescape on Gaming Customer Satisfaction, Intention to Revisit, and Desire to Stay, International Journal of Hospitality Management, 30(39): 558-567.

Lap-Kwong, D. (2017). The Role of Servicescape in Hotel Buffet Restaurant, Journal of Hotel and Business Management, 6(1): 1-8.

Lee, T. H., Fu, C. J. and Tsai, L. (2019). How Servicescape and Service Experience Affect Loyalty: Evidence from Attendees at the Taipei International Travel Fair, Journal of Convention \& Event Tourism, 20(5): 398-420.

Lin, H. H. and Wang, Y. S. (2006). An Examination of The Determinants of Customer Loyalty in Mobile Commerce Contexts. Information \& Management, 43(3): 271-282.

Lin, Y. I. (2009). The Combined Effect of Color and Music on Customer Satisfaction in Hotel Bars. Journal of Hospitality Marketing \& Management, 19(1): 22-37.

Lockwood, A. and Pyun, K (2020). Developing a Scale Measuring Customers' Servicescape Perceptions in Upscale Hotels, International Journal of Contemporary Hospitality Management, 32(1): 40-59.

Lucas, A. F. (2003). The Determinants and Effects of Slot Servicescape Satisfaction in a Las Vegas Hotel Casino, UNLV Gaming Research and Review Journal, 7(1): 1-17.

Mannan, M., Chowdhury, N., Sarker, P. and Amir, R. (2019). Modeling Customer Satisfaction and Revisit Intention in Bangladeshi Dining Restaurants, Journal of Modelling in Management, 14(4): 922-947.

Marinkovic, V., Senic, V., Ivkov, D., Dimitrovski, D. and Bjelic, M. (2014). The Antecedents of Satisfaction and Revisit Intentions for Full-Service Restaurants. Marketing Intelligence $\mathcal{E}$ Planning, 32(3): 311-327.

Mohd Wahid, D. S., Mohamad, I. N. and Fadzilah Zahari, N. S. (2012). Measuring Physical Evidences and Customers' Satisfactions at Hotels \& Resorts in Lumut, Elixir Marketing Management, 50: 10253-10256. 
Raza, A. M., Siddiquei, N. A., Awan, M. H. and Bukhari, K. (2012). Relationship Between Service Quality, Perceived Value, Satisfaction and Revisit Intention in Hotel Industry, Interdisciplinary Journal of Contemporary Research in Business, 4(8): 788-805.

Ryu, K. (2010) The Influence of Dining Environmental Perceptions on Behavioral Intentions Through Customer Satisfaction in the Upscale Restaurant Context. Annual Conference proceedings of research and academic papers. Catalina Island, Mexico, 18-22 October, pp.185-203.

Ryu, K. and Jang, S. (2008). Dinescape: A Scale for Customers Perception of Dining Environments. The Journal of Foodservice Business Research, 11(1): 2-22.

Schumacker, R. E. and Lomax, R. G. (2010). A Beginner's Guide to Structural Equation Modeling. Routledge: Newyork.

Shiel, G. and Cartwright. F. (2015). Analyzing Data from A National Assessment of Educational Achievement. Washington DC: World Bank Group.

Sunny-Hu, H. H., Kandampully, J. and Juwaheer, D. T. (2009). Relationships and Impacts of Service Quality, Perceived Value, Customer Satisfaction, and Image: An Empirical Study, The Service Industries Journal, 29(2): 111-125.

Turley, L.W. and Milliman, R. E. (2000). Atmospheric Effects on Shopping Behaviour: A Review of The Experimental Evidence, Journal of Business Research, 49(2): 193-211.

Wakefield, K.L. and Blodgett, J.G. (1999). Customer Response to Intangible and Tangible Service Factors, Psychology and Marketing, 16(1): 51-68.

Woo, E., Kim, H., and Uysal, M. (2015). Life Satisfaction and Support for Tourism Development, Annals of Tourism Research, 50: 84-97.

Yee-Man Siu, N., King Wan, Y. P. and Dong, P. (2012). The Impact of the Servicescape on the Desire to Stay in Convention and Exhibition Centers: The case of Macao, International Journal of Hospitality Management, 31: 236-246. 